\title{
PENGARUH MANAJEMEN ASET, MANAJEMEN LIABILITI, MANAJEMEN ASET LIABILITI TERHADAP ECONOMIC VALUE ADDED (EVA) PADA PERBANKAN KONVENSIONAL YANG TERDAFTAR DI BURSA EFEK INDONESIA
}

\author{
Hamidah* $^{*}$ \\ Ika Nur Setiowati* \\ Agung Dharmawan Buchdadi**
}

\begin{abstract}
Generally, company wants to optimize its profit. Properly manage the asset management, liability management and asset liability management can provide value added profits for the company. A sample of research consists of 18 banking companies listed at Indonesia Stock Exchange (IDX) during the 20052009. This research investigate the relationship net loans/total earning assets (NLA), non performing loan (NPL), liabilities/total assets (LA), equity/total assets (EA), net interest margin (NIM), loan to deposite ratio (LDR) on economic value added (EVA). The research use regression of panel data. The result show that net loans/total earning assets (NLA), liabilities/total assets $(L A)$, equity/total assets (EA), net interest margin (NIM), loan to deposite ratio (LDR) are have significant effect on economic value added (EVA) but non performing loan (NPL).
\end{abstract}

Key words: NLA, NPL, LA, EA, NIM, LDR, EVA

\section{PENDAHULUAN}

Hamidah Fakultas Ekonomi, Program Studi S1 Manajemen, Universitas Negeri Jakarta. Email: hamidahsam@yahoo. com

** Ika Nur Setiowati. Fakultas Ekonomi, Program Studi S1 Manajemen, Universitas Negeri Jakarta. Email: ikanurs.ins@gmail.com.

*** Agung Dharmawan Buchdadi. Fakultas Ekonomi, Program Studi S1 Manajemen, Universitas Negeri Jakarta. Email: agungdharmawan@feunj.ac.id
Bank merupakan suatu badan usaha atau lembaga yang menjadi salah satu faktor penting dalam perekonomian suatu negara. Masyarakat diharapkan mampu untuk memanfaatkan kehadiran bank demikian juga bank yang seharusnya mampu memberikan jasanya kepada masyarakat dengan 
baik. Namun, kenyataan yang terjadi sejak tahun 1997 hingga sekarang krisis ekonomi di Indonesia belum menunjukkan tanda-tanda pemulihan dengan baik. Diawali terjadinya krisis perbankan, dengan kondisi perbankan kemudian semakin rawan. Berbagai perkembangan ini mengakibatkan proses intermediasi oleh perbankan terganggu sehingga memberikan dampak yang kurang menguntungkan bagi perekonomian secara keseluruhan.

Keadaan buruknya kinerja keuangan perbankan, menimbulkan berbagai penelitian tentang kinerja keuangan perbankan. salah satu tolak ukur kinerja keuangan yaitu menggunakan EVA (Economic Value Added). Tolak ukur EVA dianggap mempunyai kelebihan adaptability, artinya dapat digunakan dimanapun untuk alokasi dari penghasilan, biaya dan pemanfaatan modal, bank dapat mempergunakan EVA tidak hanya untuk setiap lini produknya, dan setiap cabangnya tapi juga untuk seluruh pelanggannya yang bisa memberi keuntungan terhadap bank (Hamidah, 2006).

Dengan diundangkannya Undang-undang No.10 Tahun 1998 tentang perubahan Undang-undang No.7 Tahun 1992 tentang Perbankan diharapkan mampu menata kembali sektor perbankan yang mengalami goncangan akibat krisis dan yang paling penting diharapkan mampu mengembalikan kepercayaan masyarakat terhadap sektor perbankan di Indonesia. Untuk dapat mengembalikan kepercayaan masyarakat, maka perlu diturunkan suku bunga kredit agar permintaan terhadap pinjaman kredit semakin meningkat. Secara teori, jika permintaan atas kredit meningkat, maka pendapatan bunga meningkat, sehingga memberikan nilai tambah bagi perusahaan atau EVA naik. Penelitian oleh Hamidah (2006) menunjukkan hasil adanya hubungan signifikan antara kredit yang diberikan dengan EVA.

Dalam manajemen aset, dapat meningkatkan kredit yang disalurkan, sehingga akan memberikan nilai bagi perusahaaan, tetapi juga mendapat ancaman adanya kredit macet (Non Performing Loan), karena semakin banyak masyarakat atau pelaku bisnis membuka kredit di bank-bank lain yang menawarkan bunga kredit lebih rendah, sehingga tidak mampu memenuhi kewajibannya dalam membayar kredit yang diberikan. Dengan demikian, semakin besar kredit macet, maka akan menurunkan profit perusahaan atau tidak memberikan nilai tambah bagi perusahaan. Hasil penelitian oleh Pahlevie (2009) menunjukkan 
bahwa secara uji parsial NPL menunjukkan pengaruh signifikan negatif terhadap pertumbuhan laba, tetapi hasil yang berbeda ditunjukkan oleh penelitian Sapariyah (2010) menunjukkan bahwa variabel assets (yang dinyatakan dengan NPL) berpengaruh positif dan signifikan terhadap pertumbuhan laba.

Untuk dapat memberikan penawaran kredit kepada masyarakat, maka bank membutuhkan dana yang bersumber dari kewajiban dan ekuitas. Jika kewajiban dan ekuitas suatu bank bertambah, maka bobot hutang dan ekuitas naik, sehingga menghasilkan biaya rata-rata tertimbang kecil yang mengakibatkan penurunan terhadap Economic Value Added. Hasil penelitian Heffernan dan Meggie (2008) yaitu EA (Equity/Total Asset) berpengaruh negatif dan signifikan terhadap EVA.

Dalam mengelola keseimbangan aset dan liabiliti bank untuk menciptakan nilai tambah, penelitian ini menggunakan rasio NIM (Net Interest Margin) dan LDR (Loan Deposite Ratio). Net Interest Margin (NIM) mencerminkan kemampuan bank dalam mengendalikan risiko tingkat bunga dan kemampuan bank dalam mengelola aset liabilitinya, sehingga jika hasilnya negatif atau kecil maka akan memperkecil EVA dan jika positif maka akan memperbesar EVA. Penelitian dari Hamidah (2006) menunjukkan hasil bahwa NIM berpengaruh terhadap EVA, namun berbeda dengan hasil penelitian dari Imamah (2005) dan Budiharti (2006) yang menunjukkan NIM tidak berpengaruh terhadap EVA.

LDR (Loan Deposite Ratio) menunjukkan bahwa kemampuan bank sebagai lembaga intermediasi apakah bank tersebut mampu menyalurkan dana masyarakat yang telah dihimpun disalurkan kembali ke masyarakat yang memerlukan berupa kredit. Dengan demikian apabila LDR besar berarti kredit yang disalurkan juga besar, sehingga pendapatan operasi naik, maka EVA naik atau terciptanya pertambahan nilai bagi perusahaan. Penelitian dari Ariyanti(2010) dan Pahlevie (2009) menghasilkan pengaruh signifikan positif dengan pertumbuhan laba, namun berbeda dengan penelitian Sapariyah (2010) yang menghasilkan penelitian bahwa LDR berpengaruh tidak signifikan terhadap pertumbuhan laba. Dari berbagai penelitian empiris yang pernah dilakukan dan memberikan hasil kontradiktif serta adanya fenomena masalah yang terjadi, maka penelitian ini dilakukan 
untuk meneliti ulang variabelvariabel yang pernah diteliti.

Tujuan penelitian ini yaitu untuk menemukan pengaruh yang signifikan diantara variabel bebas dalam Faktor Manajemen Aset (FMA) yaitu Net Loans/Total Earning Assets (NLA) dan Non Performing Loan (NPL), variabel bebas dalam Faktor Manajemen Liabiliti (FML) yaitu Liabilities/Total Assets (LA) dan Equity/Total Assets (EA), dan variabel bebas dalam Faktor Manajemen Aset Liabiliti (FMAL) yaitu Net Interest Margin (NIM) dan Loan to Deposite Ratio (LDR) terhadap Variabel terikat yaitu Economic Value Added (EVA) pada perbankan konvensional yang terdaftar di Bursa Efek Indonesia (BEI) periode 2005-2009.

\section{TINJAUAN PUSTAKA}

Dalam Pasus (2007), EVA merupakan nilai ekonomi sebenarnya yang dimiliki oleh perusahaan. EVA adalah sebuah alat pengukuran kinerja sebuah perusahaan layaknya Return on Invesment (ROI), Return on Equity (ROE), ataupun Return on Assets (ROA). Namun berbeda dari alat ukur berbasis ratio yang mengukur rasio laba terhadap investasi/aset/ ekuitas, EVA mengukur nilai tambah yang dihasilkan perusahaan kepada investor.
Brigham \& Houston (2011) juga berpendapat bahwa EVA menyajikan suatu ukuran yang baik mengenai sampai sejauh mana perusahaan telah memberikan tambahan pada nilai pemegang saham. Oleh karenanya, jika manajer berfokus pada EVA, hal ini akan dapat membantu memastikan bahwa mereka telah menjalankan operasi dengan cara yang konsisten dengan tujuan untuk memastikan kekayaan pemegang saham.

Faktor manajemen aset merupakan keputusan alokasi dana atau keputusan investasi suatu bank umum dalam mempertimbangkan dana yang diperolehnya ke dalam pemilihan alternatif investasi (Hamidah, 2006). Dengan demikian alternatif investasi yang baik akan memberikan pendapatan operasi yang besar sehingga Economic Value Added (EVA) meningkat.

Keputusan dalam manajemen liabiliti merupakan keputusan dalam pemilihan sumber pendanaan. Keputusan pemilihan diversifikasi pendanaan yang efisien akan tercermin pada biaya dana (cost of fund) yang lebih rendah. Jadi semakin terdifersivikasi ke dalam alternatif elemen pendanaan yang berasal dari sumber dana yang murah maka akan meningkatkan penciptaan nilai tambah perusahaan (Hamidah, 2006). 
Manajemen Aset dan Liabiliti menurut Rivai et al, (2007) adalah suatu proses pengelolaan dana suatu bank. Artinya adalah bagaimana bank menerapkan kebijakan yang berkaitan dengan pemupukan sumber dana, baik pemupukan dari masyarakat atau dari modal sendiri, di samping kebijakan yang berkaitan dengan pengalokasian atau penempatan dana sedemikian rupa sehingga dapat mencapai tingkat pendapatan yang optimal serta sesuai dengan peraturan yang diterapkan bank sentral. Jika pengelolaan dana di alokasikan ke manajemen aset dengan baik, maka akan meningkatkan Economic Value Added (EVA).

\section{Kerangka Pemikiran}

Analisis kinerja keuangan pada perbankan digunakan oleh para pelaku bisnis maupun investor dalam menilai kemampuan bank untuk menghasilkan profit dan meningkatkan kekayaan bank. Analisis kinerja keuangan dapat diukur dari laporan keuangan yang kemudian dianalisis dengan beberapa metode. Kinerja keuangan yang sering dipakai sebagai tolak ukur adalah kinerja keuangan tradisional, yaitu standar parameter akuntansi berupa rasio-rasio keuangan seperti ROA, ROE, ROI,
RONA dan lainya. Namun pengukuran ini telah dianggap memiliki kelemahan yaitu mengabaikan ukuran dan pertumbuhan perusahaan. Analisis kinerja terbaru yang dikembangkan oleh lembaga konsultan Stern Strewart \& Co. Mulai digunakan yaitu analisis nilai tambah ekonomis (Economic Value Added). EVA dianggap lebih memberikan hasil yang menyeluruh terhadap kinerja keuangan.

Variabel terikat atau dependen yang digunakan dalam penelitian ini adalah nilai perusahaan yang diukur berdasarkan EVA (Economic Value Added). EVA dianggap proxy yang tepat untuk mengindikasikan ada tidaknya penciptaan nilai perusahaan. Jika EVA positif akan mengindikasikan terjadinya penghancuran nilai, sebaliknya jika EVA negatif mengindikasikan terjadinya penghancuran nilai.

Setiap bank akan memiliki karakteristik tersendiri dalam menentukan keputusan portfolio aset untuk mendapatkan keuntungan, keputusan perusahaan tersebut disebut Manajemen Aset. Menurut Mishkin mengatakan untuk memaksimumkan keuntungan, sebuah bank harus terus-menerus mencari kemungkinan imbal balik tertinggi atas kredit dan surat berharga, mengurangi 
risiko, dan mencukupi kebutuhan likuiditas dengan memiliki aset likuid. Dari pernyataan Mishkin ini, peneliti menggunakan variabel bebas Net Loan/Total Earning Assets (NLA) dan Non Performing Loan (NPL) untuk faktor manajemen aset. Dimana secara teori semakin tinggi penempatan pada jumlah kredit yang diberikan maka akan semakin tinggi pendapatan bunga, sehingga dapat meningkatkan penciptaan nilai bagi perusahaan, namun kebalikannya untuk NPL yaitu semakin tinggi NPL maka akan mengurangi nilai bagi perusahaan.

Faktor Manajemen Liabiliti (FML) merupakan cerminan keputusan pemilihan sumber pendanaan bank. Menurut Mishkin (2008), bank-bank harus mempunyai keputusan tentang banyaknya modal yang perlu dimiliki karena tiga alasan. Pertama, modal bank membantu mencegah kegagalan bank (bank failure), yaitu suatu situasi di mana bank tidak dapat memenuhi kewajibannya membayar deposan dan kreditor lainnya dan menjadi bangkrut. Kedua, jumlah modal mempenga-ruhi imbal balik bagi pemilik (pemegang saham) bank. ketiga, sejumlah minimum modal bank (kewajiban modal bank) diharuskan oleh otoritas/badan pengatur. Total kewajiban dan ekuitas atau modal sendiri merupakan variabel yang tepat untuk mengetahui pengaruh positif atau negatif terhadap EVA. Apabila pendanaan yang murah akan memiliki biaya rata-rata tertimbang yang kecil, maka akan semakin besar penciptaan nilai bagi perusahaan.

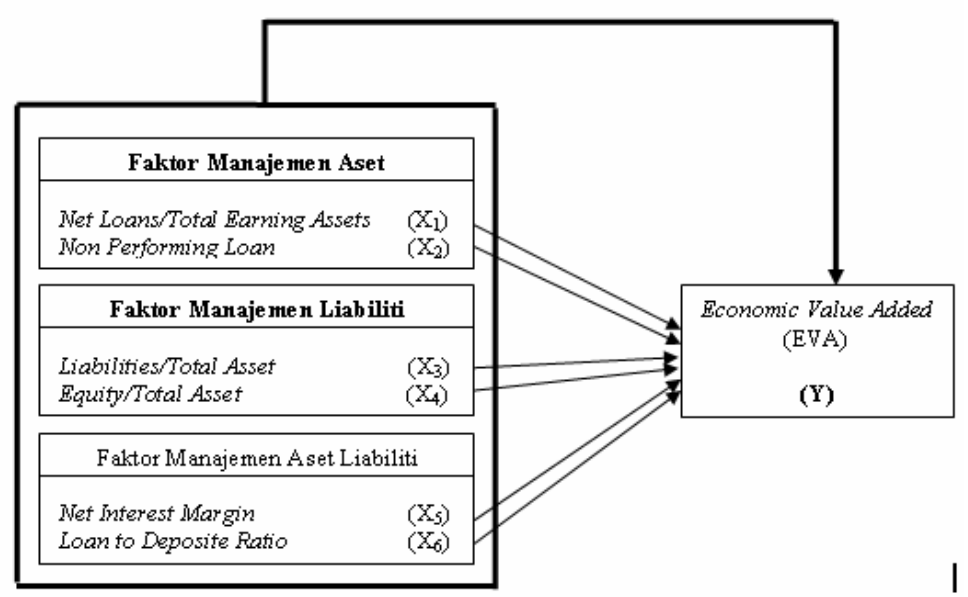

Gambar 1: Kerangka Pemikiran Pengaruh FMA, FML, FMAL Terhadap EVA 


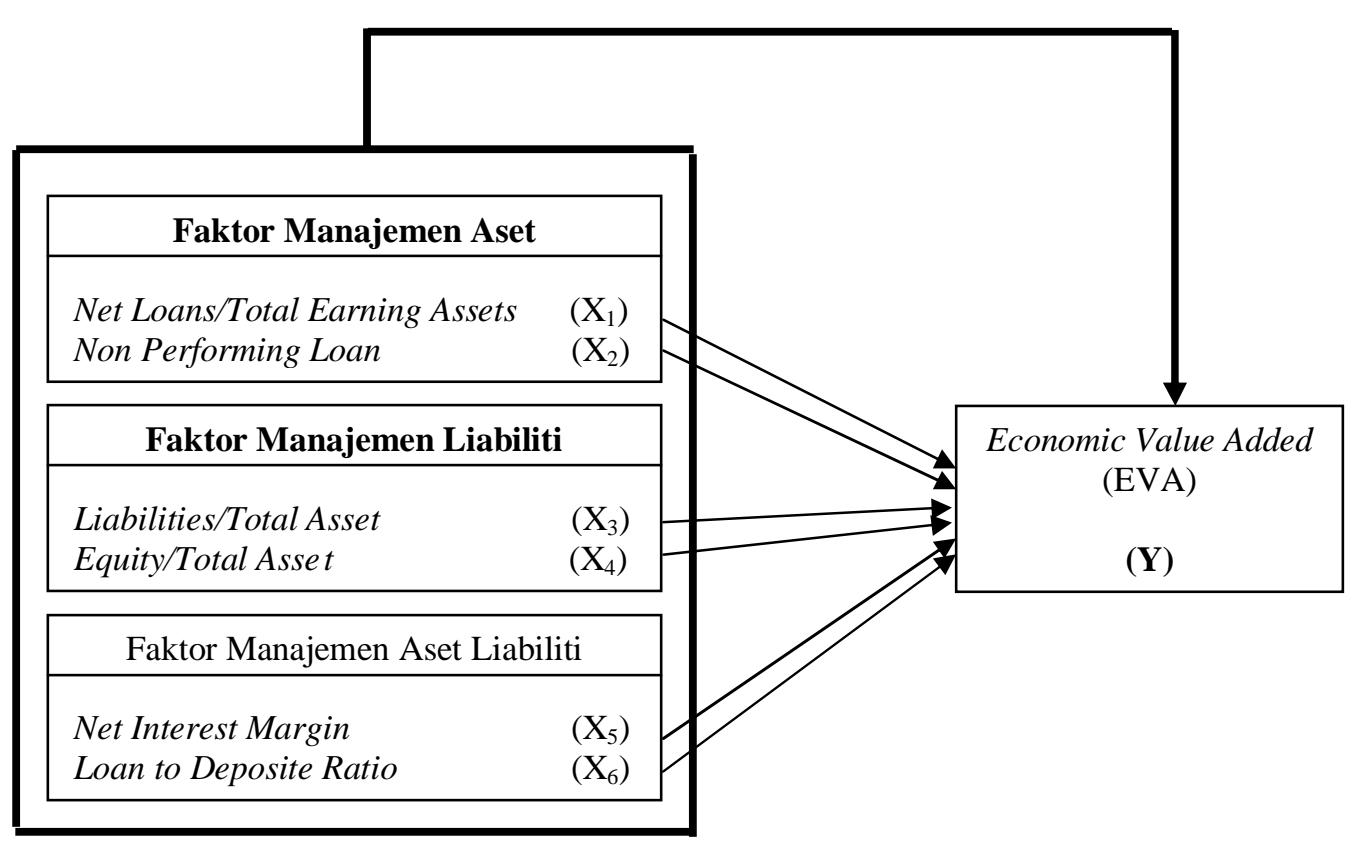

\section{Gambar 1: Kerangka Pemikiran Pengaruh FMA, FML, FMAL Terhadap EVA}

Faktor Manajemen Aset Liabiliti (FMAL) adalah kemampuan bank dalam memadukan dana yang diperoleh ke dalam aset yang berpenghasilan. Secara normatif, bank harus menjaga keseimbangan dan menghindari ketidakseimbangan. ketidakseimbangan neraca dapat terjadi karena peningkatan tajam sisi liabiliti tanpa diikuti oleh kenaikan aset yang sebanding (Hamidah, 2006). Bank yang mampu memadukan dan menjaga keseimbangan antara aset dan sumber pendanaannya akan mampu menciptakan nilai bagi perusahaan. Dalam hal ini, peneliti mengambil rasio LDR (Loan to Deposite Ratio) dan NIM (Net Interest Margin) sebagai variabel independen dari FMAL.

\section{Hipotesis}

Penelitian dari Hamidah (2006) menunjukkan bahwa rasio kredit yang disalurkan mempunyai pengaruh yang signifikan terhadap Economic Value Added (EVA). Sehingga dapat dirumuskan hipotesis sebagai berikut :

H1 : Net Loans/Total Earning Asset (NLA) berpengaruh signifikan terhadap econimc value added. Menurut penelitian yang dilakukan Pahlevie (2009) dan Sapariyah (2010) ditemukan pengaruh yang signifikan antara Non Performing Loans (NPL) dan 
Economic Value Added (EVA). Sehingga hipotesis yang dirumuskan oleh peneliti:

$\mathrm{H} 2$ : Non Performing Loan (NPL) berpengaruh signifikan terhadap Economic Value Added (EVA).

Penelitian yang dilakukan oleh Hamidah (2006) didapatkan hasil bahwa sertifikat deposito sebagai salah satu variabel kewajiban atau liabiliti menunjukkan bahwa adanya hubungan signifikan antara sertifikat deposito dengan Economic Value Added (EVA). Peneliti menggunakan variabel bebas kewajiban untuk mengetahui hubungan kewajiban secara menyeluruh dengan Economic Value Added (EVA). Sehingga peneliti merumuskan hipotesis sebagai berikut :

H3 : Liabilities/total Assets (LA) berpengaruh signifikan terhadap terhadap Economic Value Added (EVA).

Dalam penelitiannya Heffernan dan Meggie (2008) dan ditemukan bahwa EA (Equity/Total Assets) berpengaruh signifikan terhadap Economic Value Added (EVA). Sehingga peneliti merumuskan hipotesis sebagai berikut :

$\mathrm{H} 4$ : Equity/total Assets (EA) berpengaruh signifikan terhadap terhadap Economic Value Added (EVA).
Hasil penelitian dari Hamidah (2006) menunjukkan bahwa Net Interest Margin (NIM) berpengaruh signifikan terhadap Economic Value Added (EVA). Sehingga peneliti merumuskan hipotesis sebagai berikut:

H5 : Net Interest Margin (NIM) berpengaruh signifikan terhadap terhadap Economic Value Added (EVA).

Penelitian dari Ariyanti (2010) dan Pahlevie (2009) menghasilkan pengaruh signifikan antara Loan to Deposite Ratio (LDR) berpengaruh signifikan dengan pertumbuhan laba. Sehingga peneliti merumuskan hipotesis sebagai berikut:

H6 : Loan to Deposite Ratio (LDR) berpengaruh signifikan terhadap terhadap Economic Value Added (EVA).

Penelitian dari Hamidah (2006) menunjukkan bahwa variabel dalam Faktor Manajemen Aset (FMA), Faktor Manajemen Liabiliti (FML), dan Faktor Manajemen Aset Liabiliti (FMAL) berpengaruh secara simultan terhadap Economic Value Added (EVA). Sehingga peneliti merumuskan hipotesis sebagai berikut:

H7 : Variabel dalam faktor manajemen aset (Net Loans/Total Earning AssetsNLA dan Non Performing LoanNPL), faktor manajemen liabiliti 
(Liabilities/Total Assets-LA dan Equity/Total Assets-EA) dan faktor manajemen aset liabiliti (Net Interest Margin-NIM dan Loan to Deposite Ratio-LDR) berpengaruh secara simultan terhadap Economic Value Added (EVA).

\section{METODOLOGI}

Populasi yang digunakan dalam penelitian adalah perusahaan perbankan yang terdaftar pada Bursa Efek Indonesia (BEI) dengan periode 2005 - 2009. Sampel dari penelitian ini sebanyak 18 perusahaan perbankan yang menerbitkan laporan keuangan lengkap dari sebelum tahun 2005 sampai 2009. Adapun total observasi dalam penelitian ini sebanyak 79. Data diambil dari laporan keuangan yang telah diaudit. Metode penelitian ini menggunakan metode hipotesis asosiatif yaitu metode untuk mengetahui hubungan antara dua variabel atau lebih dalam sampel yang diambil dari populasi. Analisis dalam penelitian ini menggunakan regresi panel data.

Model yang diuji dalam penelitian ini adalah sebagai berikut. EVAit $=\beta_{0}+\beta_{1}$ (NLAit) $+\beta_{2}$ (NPLit) $+\beta_{3}$ (LAit) $+\beta_{4}$ (EAit) $+\beta_{5}$ (NIMit) $+\beta_{6}$ (LDRit) $+e_{t}$

Keterangan:
$\mathrm{EVA}=$ Economic Value Added NLA $=$ Net Loans/Total Earning Assets

LA = Liability/Total Assets

$\mathrm{EA}=$ Equity/Total Assets

NIM $=$ Net Interest Margin

$\mathrm{LDR}=$ Loan to Deposite Ratio

$\beta_{0}=$ Intercept (Konstanta)

$\beta_{1}, \beta_{2}, \beta_{3}, \beta_{4}, \beta_{5}, \beta_{6}=$ Koefisian parameter regresi

$\mathrm{e}=$ Eror

Variabel yang digunakan dalam penelitian ini berdasarkan pada variabel dari penelitian terdahulu. Variabel di bawah ini digunakan untuk menguji hipotesis pada penelitian ini, yang terdiri dari variabel terikat dan bebas.

Economic Value Added (EVA) sebagai variabel terikat dalam penelitian ini yang merupakan analisis nilai tambah yang dihasilkan perusahaan kepada investor. Penelitian ini menggunakan enam variabel bebas yaitu dua dari Faktor Manajemen Aset (FMA), dua dari Faktor Manajemen Liabiliti (FML), dan dua dari Faktor Manajemen Aset Liabiliti (FMAL).

Variabel bebas yang pertama dari FMA adalah Net Loans/Total Earning Assets (NLA), yaitu rasio kredit yang disalurkan yang diukur dengan membagi jumlah kredit yang diberikan terhadap aktiva produktif. Variabel kedua dari FMA adalah Non Performing Loans (NPL) yang 
merupakan kredit yang pengembalian pokok pinjaman dan pembayaran bunganya telah mengalami penundaan lebih dari satu tahun sejak jatuh tempo menurut jadwal yang telah diperjanjikan.

Liabilities/Total Assets (LA) merupakan variabel bebas dari FML, yaitu rasio total kewajiban terhadap total aset, dimana total Kewajiban terdiri dari: giro, tabungan, simpanan berjangka, sertifikat deposito, sekuritas (surat berharga yang diterbitkan), pinjaman yang diterima, kewajiban lain, pertumbuhan kewajiban komitmen kontijensi. Variabel bebas dari FML selanjutnya adalah Equity/Total
Assets (EA) yang merupakan rasio ekuitas atau dana dari modal sendiri terhadap total aset.

Variabel bebas dari FMAL yaitu Net Interest Margin (NIM) adalah besarnya rasio yang diukur dari selisih antara total bunga yang diterima atas aset yang berpenghasilan dikurangi total biaya bunga atas liabiliti yang berbunga. Variabel bebas yang terakhir dari FMAL yaitu Loan to Deposite Ratio (LDR) yang menyatakan kemampuan bank dalam membayar kembali penarikan dana yang dilakukan deposan dengan mengandalkan kredit yang diberikan sebagai sumber likuiditasnya. (Rivai,Veithzal dan Idroes,2007).

\section{Tabel 1: Operasionalisasi Varibel Penelitian}

\begin{tabular}{|c|c|c|}
\hline No. & Variabel & Indikator \\
\hline 1. & $\begin{array}{l}\text { Economic Value } \\
\text { Added (EVA) }\end{array}$ & $\begin{array}{c}\text { EVA }=\text { NOPAT }- \text { Capital Charges } \\
\text { NOPAT }=\text { Laba }_{\mathrm{t}}-\text { Pendapatan Non Operasional } \mathrm{t}_{\mathrm{t}}+\text { Penyusutan } \mathrm{t}_{\mathrm{t}} \\
\text { Capital Charges }=\text { Invested Capital } \mathrm{x} \text { WACC } \\
\text { Investes Capital }=\text { Total Hutang \& Ekuitas }- \text { Non Interest Debt } \\
\text { WACC }=\left[\left(\mathrm{k}_{\mathrm{d}} \mathrm{x}(1-\mathrm{T}) \mathrm{x} \mathrm{W}_{\mathrm{d}} \mathrm{)}\right]+\left[\mathrm{k}_{\mathrm{e}} \mathrm{x} \mathrm{W}_{\mathrm{t}}\right]\right.\end{array}$ \\
\hline 2. & $\begin{array}{l}\text { Net Loans/total } \\
\text { Earning assets } \\
\text { (NLA) }\end{array}$ & Rasio Kredit yang disalurkan $=\left[\frac{\text { Kredit Rupiah }+ \text { Kredit Valuta Asi }}{\text { Aktiva Produktif }}\right.$ \\
\hline 3. & $\begin{array}{l}\text { Non Performing } \\
\text { Loan (NPL) }\end{array}$ & Rasio NPL $=\left[\frac{\text { Kredit Bermasalah }}{\text { Total Kredit }}\right] \times 100 \%$ \\
\hline 4. & $\begin{array}{l}\text { Liabilities/Total } \\
\text { Assets (LA) }\end{array}$ & Rasio Kewajiban $=\left[\frac{\text { Total kewajiban }}{\text { Total Aset }}\right] \times 100 \%$ \\
\hline 5. & $\begin{array}{l}\text { Equity/ Total Assets } \\
\text { (EA) }\end{array}$ & \\
\hline
\end{tabular}




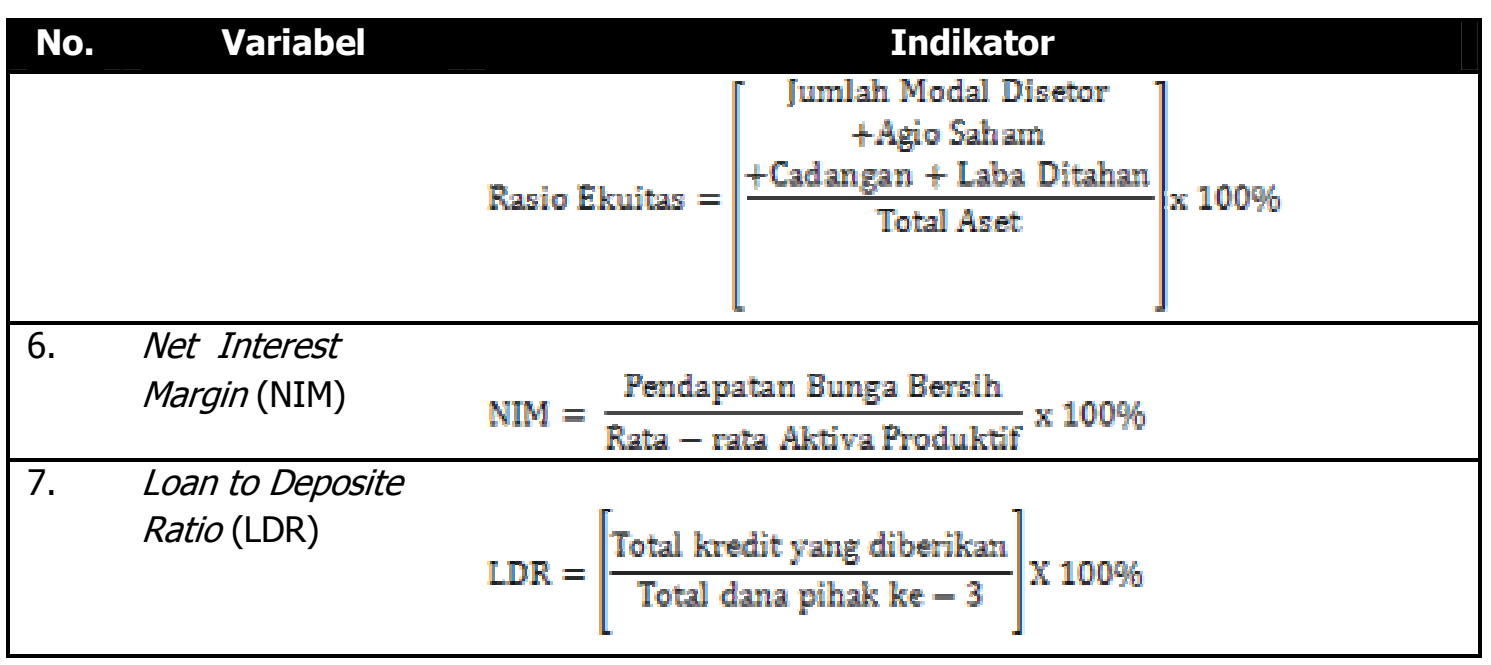

HASIL DAN PEMBAHASAN

\section{Statistika Deskriptif}

Tabel 2 menerangkan statistika deskriptif untuk semua variabel. Hasil statistika deskriptif memperlihatkan bahwa mean dari variabel EVA sebesar 6282404 (dalam jutaan rupiah). Hal ini menunjukkan bahwa rata-rata perbankan dapat menciptakan nilai tambah bagi perusahaan sebesar 6282404 (dalam jutaan rupiah). Econmic Value Added (EVA) terbesar sebesar 43782348 (dalam jutaan rupiah), Econmic Value Added (EVA) terkecil sebesar 85009.47 (dalam jutaan rupiah). Standar deviasi yang didapatkan oleh variabel EVA sebesar 8942053 (dalam jutaan rupiah). Hal ini menunjukan bahwa nilai EVA dapat menyimpang kedua sisi sejauh 8942053 (dalam jutaan rupiah).

Dalam tabel 4.1, nilai mean dari variabel NLA (Net Loans/Total Earning Asset) sebesar 62,163\%. Standar deviasi yang didapatkan oleh variabel kredit sebesar $13,411 \%$. Hal ini menunjukan bahwa nilai kredit dapat menyimpang kedua sisi sejauh $13,411 \%$. Penyaluran kredit terbesar sebesar $82,860 \%$ dari aktiva produktif yang dimilikinya dan penyaluran kredit terkecil sebesar $38,730 \%$ dari aktiva produktif yang dimilikinya. 
Tabel 2. Statistika Deskriptif

\begin{tabular}{|c|c|c|c|c|c|c|c|}
\hline Variabel & $\begin{array}{c}\text { EVA } \\
\text { (dalam } \\
\text { jutaan } \\
\text { rupiah) }\end{array}$ & $\begin{array}{l}\text { NLA } \\
(\%)\end{array}$ & $\begin{array}{l}\text { NPL } \\
(\%)\end{array}$ & $\begin{array}{l}\text { LA } \\
(\%)\end{array}$ & $\begin{array}{c}\text { EA } \\
(\%)\end{array}$ & $\begin{array}{l}\text { NIM } \\
(\%)\end{array}$ & $\begin{array}{l}\text { LDR } \\
(\%)\end{array}$ \\
\hline Mean & 6282404 & 62,163 & 5,006 & 90,899 & 9,097 & 5,607 & 71,131 \\
\hline Maximum & 43782348 & 82,860 & 27,900 & 103,280 & 16,910 & 12,150 & 96,150 \\
\hline Minimum & 85009.47 & 38,730 & 0.170 & 83,090 & $-3,280$ & 2,380 & 40,330 \\
\hline $\begin{array}{l}\text { Standar } \\
\text { Deviasi }\end{array}$ & 8942053. & 13,411 & 4,902 & 2,625 & 2,626 & 1,869 & 15,061 \\
\hline
\end{tabular}

Sumber: Data diolah oleh peneliti

Pada tabel 2 kolom NPL menunjukkan rata-rata perusahaan mengalami kredit macet sebesar $5,006 \%$ dari kredit yang disalurkan kepada masyarakat. NPL terbesar yaitu sebesar $27,90 \%$ dari total kredit yang disalurkan. Sedangkan NPL terkecil sebesar $0,17 \%$ dari total kredit yang disalurkan pada tahun. Penyimpangan nilai yang mungkin terjadi hingga 4,902 lebih kecil atau lebih besar dari nilai NPL.

Variabel Liabilities/Total Assets (LA) menggambarkan kewajiban perusahaan terhadap dana masyarakat yang menitipkan atau menginvestasikan kepada bank tersebut. Pada kolom variabel LA di tabel 4.1 terdapat nilai sebesar $90,899 \%$ dari total aktiva yang menunjukkan nilai rata-rata besarnya kewajiban perusahaan dari sisi manajemen liabilitinya. Kewajiban terbesar selama periode 2005-2009 sebesar 103,280\% dari total aktiva yang dimiliki dan kewajiban terkecil sebesar $83,09 \%$. Penyimpangan mungkin terjadi sebesar 2,625\% lebih besar atau lebih kecil dari nilai kewajibannya.

Nilai mean untuk varibel equity/total assets (EA) yaitu sebesar 9,097\%, menunjukkan rata-rata besarnya dana pihak pertama yang dimiliki perusahaan. Nilai ekuitas maksimum sebesar $16,91 \%$, sebaliknya nilai ekuitas minimum sebesar $-3,28 \%$ pada tahun 2009. Penyimpangan yang mungkin terjadi sebesar 2,626\% lebih kecil atau lebih besar dari nilai ekuitasnya.

Nilai mean pada tabel 4.1 kolom variabel Net Interest Margin (NIM) sebesar 5,607\%. Nilai rasio NIM terbesar yaitu sebesar $12,15 \%$ dan nilai rasio NIM terkecil sebesar $2,38 \%$. Standar deviasi untuk variabel NIM sebesar 1,869\%, hal ini menunjukkan bahwa kemungkinan terjadi penyimpangan 
sebesar $1,869 \%$ lebih kecil atau lebih besar dari nilai NIM.

Dalam tabel 4.1 menunjukkan nilai mean pada varibel LDR sebesar $71,131 \%$. Nilai maksimum variabel LDR sebesar 96,15\%, sedangkan nilai minimum sebesar 40,33\%. Penyimpangan yang mungkin terjadi sebesar 15,061\% lebih besar atau lebih kecil dari nilai LDR.
Untuk memilih menggunakan fixed effect atau common effect maka digunakan uji chow. Apabila probabilitas dari cross section chisuare lebih kecil dari 0,05 maka menolak $\mathrm{H}_{0}$.

$\mathrm{H}_{0}$ : Common Effect

$\mathrm{H}_{1}$ : Fixed Effect

\section{Uji Chow}

Tabel 3. Hasil Uji Chow

\begin{tabular}{|llc|}
\hline Effects Test & Statistic & Prob. \\
\hline Cross-section F & 0.418228 & 0.9675 \\
\hline $\begin{array}{l}\text { Cross-section Chi- } \\
\text { square }\end{array}$ & 8.282281 & 0.9120 \\
\hline
\end{tabular}

Sumber: Data diolah oleh peneliti dengan eviews7

Berdasarkan dari tabel 3 didapatkan nilai Prob. Cross-section Chi-square lebih dari 0,05 maka menerima model common effect. Dikarenakan model yang diterima adalah model common effect maka tidak dilanjutkan dengan uji hausman.

\section{Pembahasan}

Tabel 4 menggambarkan bahwa probabilitas $t$-statistic dari NLA (Net Loans/Total Earning Assets) sebesar 0.0289. Hal ini menunjukkan bahwa NLA berpengaruh signifikan terhadap Economic Value Added (EVA) pada level $5 \%$. Hasil ini sesuai dengan penelitian Hamidah (2006) yang menyatakan bahwa terdapat hubungan yang signifikan antara NLA dan EVA. Arah hubungan antara NLA dengan EVA adalah negatif, terlihat dari nilai koefisiennya sebesar -100.5176 . Dilihat dari rumus EVA, hubungan antara kredit dengan EVA seharusnya positif, karena semakin besar kredit yang disalurkan maka akan semakin besar juga pendapatan bunganya sehingga akan meningkatkan EVA. Namun, hasil penelitian ini tidak menunjukkan pernyataan tersebut benar, karena hasilnya menunjukkan hubungan sigifikan 
negatif antara kredit yang disalurkan dengan EVA. Dalam hal ini pendapatan operasional terbesar mungkin diperoleh dari aset non interest margin.

Probabilitas t-statistic NPL (Non Performing Loan) pada tabel 4.3 sebesar 0.3788. hal ini menunjukan bahwa terdapat hubungan yang tidak signifikan antara NPL dengan EVA. Nilai koefisien NPL sebesar 35.12221. Hal ini menunjukan bahwa terdapat hubungan yang negatif antara kedua variabel tersebut. Oleh karena itu, NPL memiliki hubungan yang negatif dan tidak signifikan terhadap penciptaan nilai tambah perusahaan atau EVA. Hasil penelitian ini berbeda dengan hasil penelitian dari Sapariyah (2010) yang menunjukkan NPL berpengaruh positif dan signifikan terhadap pertumbuhan laba. Penelitian dari Pahlevie (2009) juga menunjukkan hasil yang berbeda bahwa NPL berpengaruh negatif dan signifikan terhadap pertumbuhan laba.

Tabel 4: Hasil Regresi Panel

\begin{tabular}{|c|c|c|c|c|c|c|c|}
\hline Keterangan & C & NLA & NPL & LA & EA & NIM & LDR \\
\hline Koefisien & 6.245541 & $\begin{array}{c}- \\
100.5176\end{array}$ & $\begin{array}{c}- \\
35.12221\end{array}$ & 28055.24 & $2.51 \mathrm{E}+10$ & $1.39 \mathrm{E}+09$ & 101.6209 \\
\hline t-Statistic & 0.708162 & $\begin{array}{c}- \\
2.229882\end{array}$ & $\begin{array}{c}- \\
0.885639\end{array}$ & 2.741077 & 2.766415 & 2.520232 & 1.708615 \\
\hline $\begin{array}{c}\text { Prob. } \\
\text { t-Statistic }\end{array}$ & 0.4812 & $\begin{array}{c}0.0289 \\
\text { (sig 5\%) }\end{array}$ & 0.3788 & $\begin{array}{c}0.0077 \\
(\operatorname{sig} 1 \%)\end{array}$ & $\begin{array}{c}0.0072 \\
\text { (sig 1\%) }\end{array}$ & $\begin{array}{c}0.0140 \\
\text { (sig 5\%) }\end{array}$ & 0.0919 \\
\hline R-squared & & & & 0.191492 & & & \\
\hline F-Statistic & & & & 2.802684 & & & \\
\hline $\begin{array}{c}\text { Prob. } \\
\text { F-Statistic }\end{array}$ & & & & 0.016667 & & & \\
\hline
\end{tabular}

Sumber: Data diolah oleh peneliti dengan eviews7

Variabel Liabilities/Total Assets (LA) dari hasil regresi yang ditunjukan pada tabel 4.3 memiliki probabilitas t-stat sebesar 0,0077. Hal ini menunjukan pengaruh yang signifikan antara kewajiban terhadap nilai tambah perusahaan atau EVA pada level $1 \%$. Koefisien dari variabel LA sebesar 28055.24. Hal ini menggambarkan bahwa terdapat hubungan yang positif antara kewajiban terhadap nilai tambah perusahaan. Secara teori seharusnya hubungan antara liabilitas atau kewajiban adalah negatif, karena semakin besar kewajiban maka akan semakin besar beban hutang sehingga akan menurunkan EVA. Namun hubungan yang positif juga mungkin terjadi, 
karena jika suatu perusahaan mempunyai liabilitas yang besar dan kemudian perusahaan tersebut mengelola ke dalam manajemen aset dengan baik, maka akan menghasilkan laba yang besar. Dengan demikian kewajiban akan memberikan nilai tambah bagi perusahaan jika perusahaan dapat mengelola sumber pendanaan tersebut dengan baik sehingga akan menghasilkan laba.

Dari tabel 4.3 didapatkan hasil bahwa ekuitas mempengaruhi Economic Value Added secara signifikan. Hal ini terlihat dari probabilitas t-stat nya sebesar 0,0072 . Dari hasil regresi didapatkan juga koefisien sebesar 2.51E+10. Hal ini menunjukan bahwa terdapat hubungan yang positif antara kedua variabel tersebut. Oleh karena itu, ekuitas/total aset memiliki hubungan yang positif dan signifikan terhadap nilai tambah perusahaan. Hasil penelitian dari Heffernan dan Meggie (2008) juga menunjukkan adanya hubungan yang signifikan antara EA dengan EVA, tetapi arah hubungannya adalah negatif. Berdasarkan rumus perhitungan EVA, semakin tinggi ekuitas maka akan semakin tinggi beban ekuitas yang mengakibatkan EVA turun. Namun, dalam hal ini dapat juga berbeda arah, dimana ekuitas mempunyai hubungan yang positif terhadap EVA seperti yang ditunjukkan oleh hasil regresi penelitian ini. Alasan tersebut dikuatkan oleh pernyataan dari Heffernan dan Meggie (2008) bahwa EA mengukur kemampuan bank untuk menahan kerugian, dimana rasio EA besar maka bank mungkin memanfaatkannya untuk peluang investasi yang menguntungkan, dan apabila rasio EA menurun berarti menunjukkan adanya masalah kecukupan modal, sehingga tanda arah koefisien dapat positif atau negatif.

Hubungan antara Net Interest Margin (NIM) dengan Economic Value Added (LDR) terlihat pada tabel 4.3 dengan probabilitas t-stat sebesar 0.0140 yang lebih kecil dari $5 \%$. Hal ini menunjukan bahwa terdapat hubungan yang signifikan antara variabel NIM terhadap EVA pada tingkat $5 \%$.Koefisien dari variabel NIM sebesar $1.39 \mathrm{E}+09$. Hal ini menggambarkan bahwa terdapat hubungan yang positif pada kedua variabel tersebut. Hasil ini sesuai dengan penelitian Hamidah (2006) dan Imamah (2005) yang menyatakan bahwa NIM memiliki hubungan yang positif signifikan terhadap EVA.

Koefisien dari variabel LDR yang terdapat pada tabel 4.3 yaitu sebesar 101.6209. Oleh karena itu, terdapat hubungan yang positif 
antara LDR terhadap penciptaan nilai tambah/EVA. Adapun Probabilitas t-stat dari LDR sebesar 0.0919 yang mana angka tersebut lebih kecil dari 0,1 . Hal ini menandakan bahwa terdapat hubungan yang signifikan antara LDR terhadap EVA. Hasil penelitian ini sesuai dengan penelitian Pahlevie (2009) dan Ariyanti (2010). Oleh karena itu, LDR dalam penelitian ini memiliki pengaruh yang positif dan signifikan terhadap penciptaan nilai tambah perusahaan atau EVA.

Berdasarkan tabel 4.5, didapatkan R-squared sebesar 19,15\%. Didapatkan juga probabilitas f-statsitic sebesar 0,016667. Hal ini menunjukan bahwa NLA, NPL, LA, EA, NIM, LDR secara simultan mempengaruhi Economic Value Added (EVA).

\section{KESIMPULAN DAN SARAN}

Hasil dari Penelitian ini didapatkan bahwa variabel dalam faktor manajemen aset yaitu Net Loans/Total Earning Assets (NLA) berpengaruh negatif dan signifikan terhadap Economic Value Added (EVA) dan Non Performing Loan (NPL) berpengaruh negatif dan tidak signifikan terhadap Economic Value Added (EVA). Variabel dalam faktor manajemen liabiliti yaitu Liabilties/Total Assets (LA) dan Equity/Total Assets (EA) berpengaruh positif dan signifikan terhadap Economic Value Added (EVA). Variabel dalam faktor manajemen aset liabiliti yaitu Net Interest Margin (NIM) dan Loan to Deposite Ratio (LDR) berpengaruh positif dan signifikan terhadap Economic Value Added (EVA). Secara simultan, variabel dalam faktor manajemen aset, faktor manajemen liabiliti, faktor manajemen aset liabiliti berpengaruh terhadap Economic Value Added (EVA) dengan nilai probabilitas F-Stat sebesar 0.016667 .

Peneliti selanjutnya diharapkan dapat memperpanjang periode penelitian, sehingga bisa didapat hasil yang lebih baik dan memperluas sampel serta menambah jumlah observasi, sehingga hasil yang diperoleh mungkin lebih akurat. Untuk peneliti selanjutnya juga diharapkan untuk menambah variabel dalam faktor manajemen aset yaitu untuk non interest margin (fee based income), agar dapat mengetahui manajemen aset mana yang lebih memberikan laba bagi perusahaan perbankan. Bagi perusahaan perbankan Untuk dapat menciptakan nilai tambah, diharapkan perusahaan mampu mengendalikan risiko tingkat bunga dan mampu mengelola aset dan liabilitinya sehingga dapat 
menciptakan nilai tambah bagi perusahaan.

\section{REFERENSI}

Ariyanti Lilis E., 2010. Analisis Pengaruh CAR, NIM, LDR, NPL, BOPO, ROA dan Kualitas Aktiva Produktif Terhadap Perubahan Laba pada Bank Umum di Indonesia. Tesis. Universitas Diponegoro Semarang. Semarang.

Bringham, Eugene F. Joel $F$ Houston. 2011. Dasar - Dasar Manajemen Keuangan. Edisi 11 Buku 2. Penerjemah : Ali Akbar Yulianto. Jakarta : Salemba Empat.

Budiharti, Lusi. 2006. Analisis Kinerja Keuangan PT. Bank Rakyat Indonesia (Persero) Tbk 2004-2005 (Pengaruh Rasio-rasio Keuangan Economic Value Added-EVA dan Pengaruh EVA terhadap Market Value Added-MVA). Skripsi. Institut Pertanian Bogor. Bogor. Eviews 7.1 Users Guide

Hamidah. 2006. Analisis Penciptaan Nilai Tambah Manajemen Aset dan Liabiliti Perbankan di Indonesia. Jurnal Keuangan dan Perbankan, vol. 8, no. 2, hlm. 129-141.

Heffernan, S dan Maggie, F. 2008. Determinants of Banking
Performance in China. Jurnal of Social Science Research Network.

Imamah, H. 2005. Kinerja Keuangan PT. Bank mandiri (Persero) Tbk 2003-2004 (Hubungan Rasio Keuangan Dengan Economic Value Added-EVA). Skripsi. Institut Pertanian Bogor. Bogor.

Mishkin, Frederic. S. 2008. The Economics of Money, Banking and Financial Markets, $8^{\text {th }}$ edition. Jakarta: Salemba Empat.

Pahlevie, Nu'man H. 2009. Analisis Pengaruh CAR, NIM, LDR, NPL, BOPO dan EAQ terhadap Perubahan Laba (Studi Empiris Pada Bank Umum di Indonesia periode Laporan Keuangan Tahun 2004-2007). Tesis. Universitas Diponegoro Semarang. Semarang.

Pasus, Siti. I. P. 2007. Analisis Pengaruh Rasio-rasio Keuangan dan Economic Value AddedEVA terhadap Market Value Added-MVA (Studi Kasus PT. Bank Danamon Indonesia, Tbk). Skripsi. Institut Pertanian Bogor. Bogor.

Rivai, V., Veithzal, Andria P., and Idroes, Ferry N. 2007. Bank and Financial Institution Management (Conventional \& 
Syariah System). Jakarta: PT Rajagrafindo Persada.

Sapariyah, Rina A. 2010. Pengaruh

Rasio Capital, Assets, Earning, dan Liquidity Terhadap

Pertumbuhan Laba pada
Perbankan di Indonesia (Study Empiris pada Perbankan di Indonesia). Jurnal Ekonomi Bisnis dan Perbankan, vol. 18, no. 13. 